Proc. of the XI Int. Conf. - Ion Implantation and other Applications of Ions and Electrons, Kazimierz Dolny 2016

\title{
Identification and Fragmentation of Cefalosporins, Lincosamides, Levofloxacin, Doxycycline, Vancomycin by ESI-MS
}

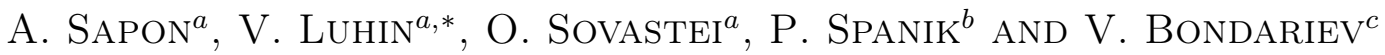 \\ ${ }^{a}$ Belarusian State University of Technology, 13a Sverdlova Str., 220050 Minsk, Belarus \\ ${ }^{b}$ University of Zilina, 1, Univerzitná Str., 01026 Žilina, Slovak Republic \\ ${ }^{c}$ Lublin University of Technology, Nadbystrzycka 38a, 20-618 Lublin, Poland
}

\begin{abstract}
The aim of the paper is the identification of the most frequently used antibiotics such as cefazolin, cefuroxime, cefotaxime, ceftriaxone, ceftazidime, lyncomycin, clindamycin, levofloxacin, doxycycline and vancomycin by electrospray ionization mass spectrometry interface in positive and negative modes. The fragmentation pathways of the group of antibiotics were colligated on the basis of the obtained ESI mass spectra. Generally, the positive ion spectra of antibiotics are higher in intensity including an $[\mathrm{M}+\mathrm{H}]^{+}$ion and producing less fragmentation as well as more informative compared to the negative ion spectra. Only ESI of levofloxacin in positive and negative modes with the chosen tune parameters leads to degradation of molecular ion, so the parent ion does not appear in the mass spectra. The group of antibiotics (cephalosporins and lincosamides) shows the same characteristic fragmentation. These setup parameters were successfully applied for the routine determination of antibiotics in their pharmaceutical dosage forms and other objects. Data base was developed for identification of antibiotics by comparison of their molecular and fragment ions.
\end{abstract}

DOI: 10.12693/APhysPolA.132.236

PACS/topics: 32.10.Bi, 33.15.Ta, 82.80.-d

\section{Introduction}

Antibiotics from the cephalosporin, fluoroquinolone, lincosamide, tetracycline groups are part of antimicrobial agents widely applied to treat infections. In quality control procedures of pharmaceuticals, quantitative analysis of antibiotics trace level in food and environmental objects requires application of effective and sensitive methods in order to protect consumers. For this purpose mass spectrometry is one of the most powerful and sensitive techniques to investigate complicated structures such as like antibiotics.

The mass spectrometry (MS) method is based on the ionization of molecules, fragmentation into characteristic ions, separation and registration of these ions according to their mass-to-charge ratio. Coupled with such soft way of fragmentation of molecules, electrospray ionization (ESI) is also a rapid, informative and reliable method [1]. Furthermore, many antibiotics are nonvolatile with high molecular weights. They respond well in ESI which usually makes high pressure liquid chromatography-MS (HPLC-MS) the technique of choice for their analysis [2]. In addition, most of antibiotics are characterized by both amino and carboxylic functionalities in their chemical structure and could ionize in both positive and negative modes typically producing $[\mathrm{M}+\mathrm{H}]^{+},[\mathrm{M}+\mathrm{Na}]^{+}$and $[\mathrm{M}+\mathrm{K}]^{+}$or $[\mathrm{M}-\mathrm{H}]^{-}$ions

*corresponding author; e-mail: Luhin_Valery@mail.ru thus providing more information to facilitate drug investigations $[3,4]$.

The purpose of this study was to find optimized conditions of ESI and trend of molecular fragmentation of each antibiotic in order to identify them in pharmaceuticals and other objects as well as to develop further quantitative methodic. The research targets were samples of cefazolin, cefuroxime, cefotaxime, ceftriaxone, ceftazidime, lyncomycin, clindamycin, levofloxacin, doxycycline and vancomycin.

\section{Experimental details and results}

$0.1-1 \mathrm{mg}$ of substances of antibiotics were accurately weighed and then dissolved in $1 \mathrm{~mL}$ acetonitrile (Fisher Scientific, UK) or methanol (Merck, Germany). The organic solvents were of HPLC-grade. Accurate mass data of molecular ions and fragments of the antibiotic were obtained employing a high resolution mass-spectrometer "Waters" with the diode-array PDA 996 and the massdetectors Micromass ZQ 2000, equipped with an ESI.

According to the previous investigations [5], there were obtained the following tune parameters for optimal detection: capillary voltage at $3 \mathrm{kV}$, cone voltage at 20$40 \mathrm{~V}$, extractor voltage at $2 \mathrm{~V}$, desolvation temperature at $200-350{ }^{\circ} \mathrm{C}$, source temperature at $100^{\circ} \mathrm{C}$; cone gas flow at $50 \mathrm{~L} / \mathrm{h}$, desolvation gas flow at $300 \mathrm{~L} / \mathrm{h}$. In this paper there are chosen antibiotics with different structure to confirm or specify these spectrometric conditions. Since some antibiotics have both basic and acidic functional groups, the ESI interface was set in positive and negative modes. Mechanism of ionization was investiga- 
ted by direct sample introduction into the mass spectrometer. According to the fragmentation mechanism of mass spectrometry, antibiotics from the same group have some similar product ions. The combined mass information, accurate mass, neutral losses, nitrogen rule, isotopic abundance are effectively applied to establish and explain the fragmentation pathway of antibiotics under investigation.

The $\beta$-lactam ring and the amide group of cephalosporins include nitrogen atoms. For this reason the samples were detected in the positive mode [6]. The results for five samples were almost the same. Every mass spectrum of positive mode has an unbroken $\beta$ lactam ring and includes the line of characteristic parent ion $[\mathrm{M}+\mathrm{H}]^{+}$or $[\mathrm{M}+\mathrm{Na}]^{+}$, daughter ions $\left[\mathrm{M}-\mathrm{R}_{1}+\mathrm{H}\right]^{+}$, $\left[\mathrm{M}-\mathrm{R}_{1}-\mathrm{COOH}+\mathrm{H}\right]^{+},\left[\mathrm{M}-\mathrm{R}_{1}-\mathrm{R}_{2}-\mathrm{COOH}+\mathrm{H}_{2} \mathrm{O}+\mathrm{H}\right]^{+}$and there was amino functionality $\left[\mathrm{M}-\mathrm{NH}_{2}\right]^{+}$. Furthermore, the mass spectrum of cefotaxim includes such ion as $\left[\mathrm{M}+\mathrm{R}_{1}+\mathrm{H}\right]^{+}$. The typical direction of molecule fragmentation of cephalosporin antibiotics is given in Fig. 1.

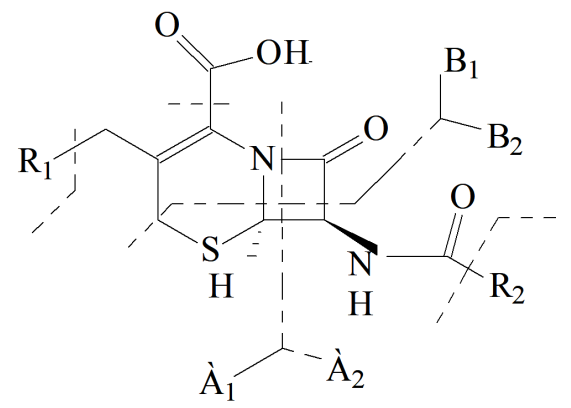

Fig. 1. Mass spectral fragmentation pathway of cephalosporin antibiotic.

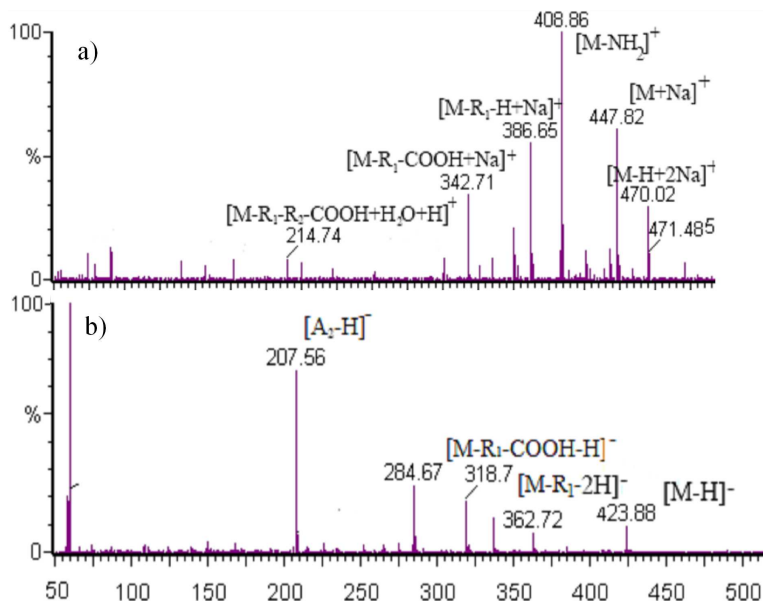

Fig. 2. Mass spectra of cefuroxime by ESI in positive (a) and negative (b) modes.

Also cephalosporins of interest have a carboxylic group and there was used the negative mode of ESI by the deprotonation reaction. This resulted in breaking the $\beta$ - lactam ring in the pathways A and B (Fig. 1). As a result, the mass spectrum of that mode had the ions [M$\mathrm{H}]^{-},[\mathrm{M}-\mathrm{COOH}-\mathrm{H}]^{-},\left[\mathrm{M}-\mathrm{R}_{1}-\mathrm{H}\right]^{-},\left[\mathrm{M}-\mathrm{R}_{1}-\mathrm{COOH}-\mathrm{H}\right]^{-}$, $\left[\mathrm{A}_{2}-\mathrm{H}\right]^{-}$. There were also daughter ions consisting of the structures $\mathrm{B}_{1}, \mathrm{~B}_{2}$ with different cleavages. However, the intensity of cephalosporin parent ion was found to be the highest in the positive mode as compared to the negative one. The mass spectra of cefuroxime by ESI in the positive and negative modes are presented in Fig. 2.

The analysis of lincosamides is challenging due to a lack of any significant chromophore or fluorophore in these molecules. The developing method ESI-MS could solve some barriers in the area of identification and quantitative analysis of lincosamides [7-9]. The optimal mass spectrometric conditions for detection of most analytes were obtained in the positive ion mode, in which not only molecular ion is saved but some characteristic ions appear. There were shown such diagnostic fragments of lincomycin as a molecular ion and its derivatives added or lost $\mathrm{H}_{2} \mathrm{O}$ or $\mathrm{HCl}$. Removal of methanethiol, 3-propyl$N$-methylpyrrolidine $\left(\mathrm{A}_{1}\right)$ is specific and useful for the identification of lincosamides and related impurities. Molecule degradation of lincosamides is presented in Fig. 3.

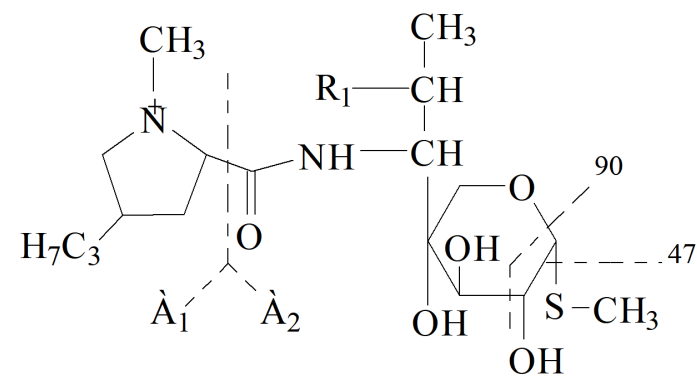

Fig. 3. Mass spectral fragmentation pathway of lincosamides.

Every mass-spectrum of negative ESI consisted of a line of characteristic molecular ion $[\mathrm{M}-\mathrm{H}]^{-}$, typical daughter ions at $m / z 126,205,219$ and such specific ions as $m / z 253,277,325$ for lincomycin and $m / z 140,333,388$ for clyndamycin. Supposedly breaking bond occurred in $\mathrm{A}_{1}$, too, and there were many fragments that corresponded to the intensive negative ion $m / z 126$.

Good interpretation of the results was obtained for doxycycline in the positive and negative modes under the above mentioned conditions. For tetracycline the class-specific fragment was at $m / z 153.8$ in the positive mode $[10]$ and according to our research for doxycycline this ion was at $m / z 153.99$. However, the other intensive specific-product ion at $m / z 428.14,321.11$ and the parent ion at $m / z 445.12$ were in the mass spectrum. These four ions occurred in some spectra and their coupling could be used for identification of doxycycline in pharmaceutical and biological objects. The mass-spectrum of negative mode of doxycycline consisted of intensive line of the characteristic parent ion $[\mathrm{M}-\mathrm{H}]^{-}$at $m / z 443.01$ and 
weak intensive daughter ions. In addition, the fragmentation pathway of doxycycline under negative ESI included breaking of bonds next to the ketonic group or cleavage $\mathrm{A}_{2}(m / z 141 \mathrm{Da})$ from the precursor ion. Thus, specific product fragments under negative ESI are at $m / z 141.87$ and $217.00\left(\mathrm{~A}_{1}\right)$ (Fig. 4, Table I at the end). Moreover, such ions as $[2 \mathrm{M}+\mathrm{H}]^{+}$and $[2 \mathrm{M}-\mathrm{H}]^{-}$were characteristic of doxycycline.

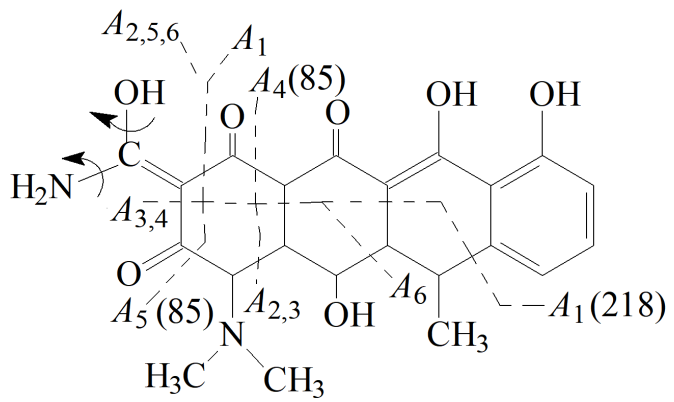

Fig. 4. Mass spectral fragmentation pathway of doxycycline.

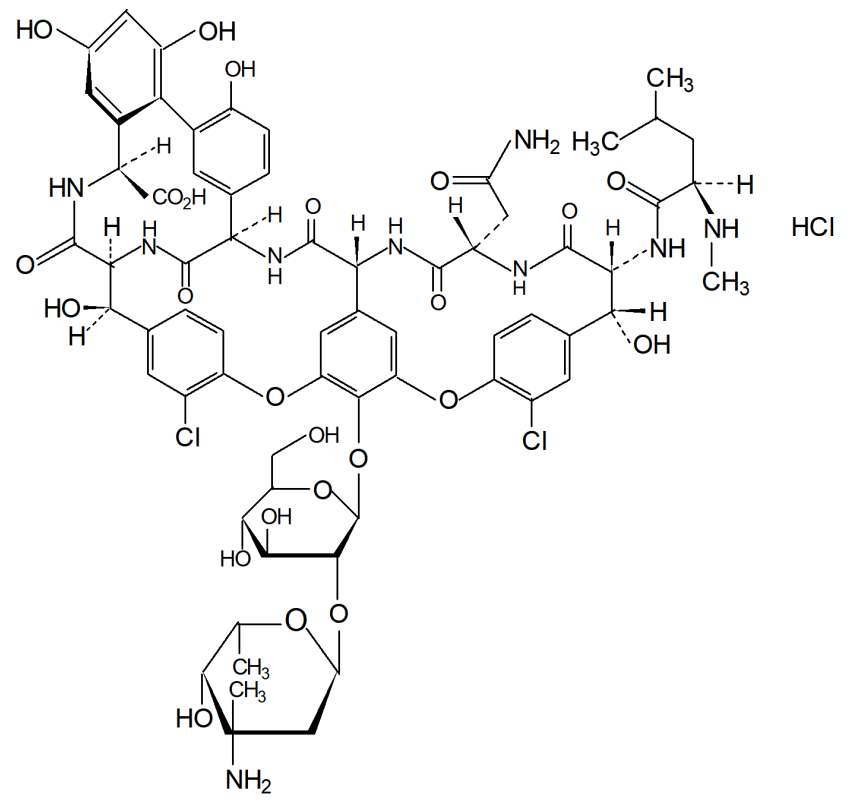

Fig. 5. Molecular structure of vancomycin hydrochloride.

Electrospray ionization of levofloxacin in the positive mode under the proposed conditions leads to breaking the molecular ion into many daughter ions. The most intensive of them are presented in Table I. The same situation was in the negative mode with the most intensive ion at $m / z 126.70$ Da. Further to this reaction of polymerization of product ions existed.

The structure of vancomycin is shown in Fig. 5. Electrospray ionization of this antibiotic in the positive mode under chosen tune parameters results in appearance of strong intensity molecular ion at $m / z$ 1450.44. The parent ion with removal of $-\mathrm{NH}_{2}$ or $-\mathrm{CONH}_{2}$ occurred in the negative ESI. All of them are characteristic and useful for identification.

\section{Conclusions}

The results of the study showed that both modes of ionization are useful to study molecular structure and fragmentation. Useful and characteristic fragment ions have been found to propose a plausible fragmentation pathway for ten investigated antibiotics. The positive ion spectra of cephalosporin antibiotics are higher in intensity including $[\mathrm{M}+\mathrm{H}]^{+}$ion and producing less fragmentation and more information as compared to the negative ion spectra. Only ESI of levofloxacin in the positive and negative modes under chosen tune parameters led to degradation of molecular ion, so the parent ion did not exist in the mass spectra. The data base of antibiotics was developed and all the spectra were correctly identified. The HPLC-MS with ESI based method on comparison of characteristic ions is potential for rapid identification of antibiotics in their pharmaceutical formulation, biological and nature objects providing a high specificity.

\section{References}

[1] K. Benkenstock, Ph.D. Thesis, KTH, Royal Institute of Technology, Stockholm 2008.

[2] G. Deng, G. Sanyal, J. Pharm. Biomed. Anal. 40, 528 (2006).

[3] M. Narayanam, T. Handa, P. Sharma, S. Jhajra, P.K. Muthe, P.K. Dappili, R.P. Shah, S. Singh, J. Pharm. Biomed. Anal. 87, 191 (2014).

[4] E. Nägele, R. Moritz, J. Am. Soc. Mass Spectrom. 16, 1670 (2005).

[5] A. Likhtarovich, V. Luhin, O. Sovastei, P. Zukowski, M. Dado, Acta Phys. Pol. A 128, 901 (2015).

[6] Chong Xiao-Meng, Hu Chang-Qin, Chromatographia 68, 759 (2008).

[7] K. Vucićevic-Prcetic, R. Cservenak, N. Radulovic, J. Pharm. Biomed. Anal. 56, 736 (2011).

[8] Della Wai-Mei Sin, Yiu-Chung Wong, Alec ChunBong, J. Pharm. Biomed. Anal. 34, 651 (2004).

[9] Hui Zhou, Zhiguo Zheng, Shihua Wu, Yuanpo Tai, Xiaoji Cao, Yuanjiang Pan, J. Pharm. Biomed. Anal. 41, 1116 (2006).

[10] M.E. Dasenaki, N.S. Thomaidis, Anal. Chim. Acta 672, 93 (2010). 
Characteristic molecular and product ions of investigated antibiotics.

TABLE I

\begin{tabular}{|c|c|c|c|c|c|c|c|}
\hline \multirow{2}{*}{ Antibiotic } & \multirow{2}{*}{$R_{1}$} & \multirow{2}{*}{$R_{2}$} & Molecular & Product 1 & Product 2 & Product 3 & Other \\
\hline & & & \multicolumn{5}{|c|}{ ion, $m / z$ [Da] } \\
\hline \multirow{2}{*}{$\begin{array}{l}\text { cefazolin } \\
454.51 \\
\text { (Fig. 1) }\end{array}$} & \multirow{2}{*}{$\underset{131}{\mathrm{~N}_{\mathrm{S}}^{-N}}$} & \multirow{2}{*}{$\begin{array}{c}-\mathrm{CH}_{2} \\
\mathbb{N}_{\mathrm{N}}^{-\mathrm{N}} \\
83\end{array}$} & $\begin{array}{c}453.61 \\
{[\mathrm{M}-\mathrm{H}]^{-}}\end{array}$ & $\begin{array}{c}408.56[\mathrm{M} \\
-\mathrm{COOH}-\mathrm{H}]^{-}\end{array}$ & $\begin{array}{l}277.13\left[\mathrm{M}-\mathrm{R}_{1}\right. \\
-\mathrm{COOH}-\mathrm{H}]^{-}\end{array}$ & $\begin{array}{c}166.84 \\
{\left[\mathrm{~B}_{1}-\mathrm{H}\right]^{-}}\end{array}$ & $\begin{array}{c}115.71\left[\mathrm{~B}_{2}-\mathrm{N}_{4}\right. \\
\left.\mathrm{CHNH}_{2}-\mathrm{H}\right]^{-} ; 157.16\end{array}$ \\
\hline & & & $\begin{array}{c}477.53 \\
{[\mathrm{M}+\mathrm{Na}]^{+}}\end{array}$ & 441.19 & 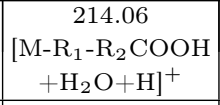 & $\begin{array}{c}158.16 \\
{\left[\mathrm{C}_{6} \mathrm{H}_{7} \mathrm{NO}_{2} \mathrm{~S}+\mathrm{H}\right]^{+}} \\
\end{array}$ & $\begin{array}{l}537.30 ; 339.10 \\
367.02 ; 202.07\end{array}$ \\
\hline \multirow{2}{*}{$\begin{array}{c}\text { cefuroxime } \\
424.39 \\
\text { (Fig. 1) }\end{array}$} & \multirow{2}{*}{60} & \multirow{2}{*}{$\mathrm{N}_{124}$} & $\begin{array}{c}423.88 \\
{[\mathrm{M}-\mathrm{H}]^{-}}\end{array}$ & $\begin{array}{c}362.72 \\
{\left[\mathrm{M}-\mathrm{R}_{1}-\mathrm{H}\right]^{-}}\end{array}$ & $\begin{array}{l}318.71\left[\mathrm{M}-\mathrm{R}_{1}\right. \\
-\mathrm{COOH}-\mathrm{H}]^{-}\end{array}$ & $\begin{array}{c}207.56 \\
{\left[\mathrm{~B}_{1}-\mathrm{H}\right]^{-}}\end{array}$ & 284.67 \\
\hline & & & $\begin{array}{l}447.62[\mathrm{M}+\mathrm{H}]^{+}, \\
469.76[\mathrm{M}+\mathrm{Na}]^{+} \\
\end{array}$ & $\begin{array}{c}408.66 \\
{\left[{\left.\mathrm{M}-\mathrm{NH}_{2}\right]^{+}}^{+}\right.}\end{array}$ & $\begin{array}{c}386.72 \\
{\left[\mathrm{M}-\mathrm{R}_{1}-\mathrm{H}+\mathrm{Na}\right]^{+}} \\
\end{array}$ & $\begin{array}{c}214.41\left[\mathrm{M}-\mathrm{R}_{1}-\mathrm{R}_{2}\right. \\
\left.-\mathrm{COOH}+\mathrm{H}_{2} \mathrm{O}+\mathrm{H}\right]^{+}\end{array}$ & $\begin{array}{c}342.71\left[\mathrm{M}-\mathrm{CO}_{2} \mathrm{NH}_{2}\right. \\
-\mathrm{COOH}+\mathrm{Na}]^{+} \\
\end{array}$ \\
\hline \multirow{2}{*}{$\begin{array}{c}\text { cefotaxime } \\
455.47 \\
\text { (Fig. 1) }\end{array}$} & \multirow{2}{*}{${ }_{59}^{\mathrm{CH}_{3}}$} & \multirow[b]{2}{*}{$156^{-\mathrm{CH}_{3}}$} & $\begin{array}{c}454.04[\mathrm{M}-\mathrm{H}]^{-} \\
475.96 \\
{[\mathrm{M}+\mathrm{Na}-2 \mathrm{H}]^{-}} \\
\end{array}$ & 162.98 & $\begin{array}{l}318.03\left[\mathrm{M}-\mathrm{R}_{1}\right. \\
-\mathrm{COOH}-\mathrm{H}]^{-}\end{array}$ & $239.03\left[\mathrm{~B}_{1}-\mathrm{H}\right]^{-}$ & $\begin{array}{l}123.83\left[\mathrm{~B}_{1}-\mathrm{H}_{2} \mathrm{O}-2 \mathrm{CO}-\mathrm{H}\right]^{-} \\
96.67\left[\mathrm{~B}_{1}-\mathrm{COOH}-2 \mathrm{CO}-\mathrm{H}\right]^{-}\end{array}$ \\
\hline & & & {$[\mathrm{M}+\mathrm{H}]^{+}-$} & $\begin{array}{c}537.36 \\
{\left[\mathrm{M}+\mathrm{R}_{1}+\mathrm{Na}\right]^{+}}\end{array}$ & 475.31 & $\begin{array}{c}214.41\left[\mathrm{M}-\mathrm{R}_{1}-\mathrm{R}_{2}\right. \\
\left.-\mathrm{COOH}+\mathrm{H}_{2} \mathrm{O}+\mathrm{H}\right]^{+} \\
\end{array}$ & $\begin{array}{c}701.51 ; 296.39 \\
324.43 ; 175.03 \\
{\left[\mathrm{R}_{2}+\mathrm{H}_{2} \mathrm{O}+\mathrm{H}\right]^{+}} \\
\end{array}$ \\
\hline \multirow{2}{*}{$\begin{array}{c}\text { ceftriaxone } \\
554.58 \\
\text { (Fig. 1) }\end{array}$} & \multirow[b]{2}{*}{126} & \multirow[b]{2}{*}{156} & $\begin{array}{r}553.47 \\
{[\mathrm{M}-\mathrm{H}]^{-}}\end{array}$ & $\begin{array}{c}508.91 \\
{[\mathrm{M}} \\
-\mathrm{COOH}-\mathrm{H}]^{-} \\
\end{array}$ & $\begin{array}{c}350.00 \\
{\left[\mathrm{M}-\mathrm{R}_{1}\right.} \\
-\mathrm{COOH}-\mathrm{H}]^{-} \\
\end{array}$ & $\begin{array}{c}239.03 \\
{\left[\mathrm{~B}_{1}-\mathrm{H}\right]^{-}}\end{array}$ & $\begin{array}{c}157.97 \\
{\left[\mathrm{~B}_{2}-\mathrm{C}_{3} \mathrm{NS}_{-} \mathrm{NH}_{2}-\mathrm{H}\right]^{-}} \\
283.15 ; 205.17\end{array}$ \\
\hline & & & {$[\mathrm{M}+\mathrm{H}]^{+}-$} & 621.79 & 172.72 & $\begin{array}{c}214.41\left[\mathrm{M}-\mathrm{R}_{1}-\mathrm{R}_{2}\right. \\
\left.-\mathrm{COOH}+\mathrm{H}_{2} \mathrm{O}+\mathrm{H}\right]^{+}\end{array}$ & $\begin{array}{l}116.35 ; 140.48 \\
226.44 ; 440.44 \\
\end{array}$ \\
\hline \multirow[t]{2}{*}{$\begin{array}{c}\text { ceftazidime } \\
546.58 \\
\text { (Fig. 1) }\end{array}$} & \multirow[t]{2}{*}{79} & \multirow{2}{*}{ ó } & $\begin{array}{c}545.09 \\
{[\mathrm{M}-\mathrm{H}]^{-}}\end{array}$ & $\begin{array}{c}529.99 \\
{\left[\mathrm{M}-\mathrm{NH}_{2}-\mathrm{H}\right]^{-}}\end{array}$ & $\begin{array}{l}271.03\left[\mathrm{~B}_{2}-\mathrm{CO}\right. \\
\left.-\mathrm{NH}-\mathrm{CH}_{2}-\mathrm{H}\right]^{-}\end{array}$ & $\begin{array}{c}206.96 \\
{\left[\mathrm{~B}_{2}-\mathrm{CO}\right]^{-}}\end{array}$ & $\begin{array}{c}123.83\left[\mathrm{~B}_{1}-\mathrm{CH}_{2}-\mathrm{R}_{1}-\mathrm{H}\right]^{-} \\
168.97\left[\mathrm{~B}_{2}-\mathrm{CONHCH}\right. \\
\left.-\mathrm{OC}\left(\mathrm{CH}_{3}\right)_{2} \mathrm{COOH}-\mathrm{H}\right]^{-} \\
134.90 ; 102.73 \\
{\left[\mathrm{OC}\left(\mathrm{CH}_{3}\right)_{2} \mathrm{COOH}-\mathrm{H}\right]^{-}}\end{array}$ \\
\hline & & & $\begin{array}{c}547.09 \\
{[\mathrm{M}+\mathrm{H}]^{+}} \\
\end{array}$ & $\begin{array}{c}468.00 \\
{\left[\mathrm{M}-\mathrm{R}_{1}+\mathrm{H}\right]^{+}}\end{array}$ & $\begin{array}{r}167.02\left[\mathrm{R}_{1}-\mathrm{CO}\right. \\
\left.-\mathrm{COOH}-\mathrm{NH}_{2}\right]^{+}\end{array}$ & $\begin{array}{c}142.00\left[\mathrm{R}_{2}-\mathrm{CO}\right. \\
\left.-\mathrm{COOHC}\left(\mathrm{CH}_{3}\right)_{2}+\mathrm{H}\right]^{+}\end{array}$ & $\begin{array}{c}79.61\left[\mathrm{R}_{1}\right] ; 99.80 \\
296.39 ; 324.43 \\
475.24 ; 701.44 \\
\end{array}$ \\
\hline $\begin{array}{c}\text { lincomycin } \\
406.54 \\
\text { (Fig. 3) }\end{array}$ & $-\mathrm{OH}$ & - & $\begin{array}{c}405.24[\mathrm{M}-\mathrm{H}]^{-} \\
441.12 \\
{\left[\mathrm{M}+2 \mathrm{H}_{2} \mathrm{O}-\mathrm{H}\right]^{-}} \\
\end{array}$ & $\begin{array}{c}169.17 \\
{\left[\mathrm{~A}_{1} \mathrm{CONH}\right]^{-}}\end{array}$ & 126.76 & 325.08 & $\begin{array}{l}277.29 ; 219.15 \\
205.07 ; 253.17\end{array}$ \\
\hline \multirow{2}{*}{$\begin{array}{c}\text { clindamycin } \\
424.98(\mathrm{M}) \\
\text { or clindamycin } \\
\text { phosphate } \\
504.96\left(\mathrm{M}^{\prime}\right) \\
\text { (Fig. } 3)\end{array}$} & \multirow[t]{2}{*}{$-\mathrm{Cl}$} & \multirow[t]{2}{*}{-} & $\begin{array}{c}503.04 \\
{\left[\mathrm{M}^{\prime}-\mathrm{H}\right]^{-}}\end{array}$ & $\begin{array}{c}467.15 \\
{\left[\mathrm{M}^{\prime}-\mathrm{HCl}-\mathrm{H}\right]^{-}}\end{array}$ & $\begin{array}{c}333.37 \\
{\left[\mathrm{M}-\mathrm{CH}_{3} \mathrm{SC}_{2}\right.} \\
\left.\mathrm{H}_{2} \mathrm{OH}-\mathrm{H}\right]^{-} \\
\end{array}$ & 126.83 & $\begin{array}{c}388.67 ; 219.21 \\
205.20 ; 140.96 \\
96.74 \\
\end{array}$ \\
\hline & & & $\begin{array}{c}425.27 \\
{[\mathrm{M}+\mathrm{H}]^{+}} \\
505.19 \\
{\left[\mathrm{M}^{\prime}+\mathrm{H}\right]^{+}} \\
\end{array}$ & $\begin{array}{l}126.04 \\
{\left[\mathrm{~A}_{1}\right]^{+}}\end{array}$ & $\begin{array}{c}487.18 \\
{\left[\mathrm{M}^{\prime}-\mathrm{H}_{2} \mathrm{O}+\mathrm{H}\right]^{+}}\end{array}$ & 475.31 & 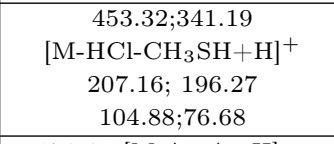 \\
\hline \multirow{2}{*}{$\begin{array}{c}\text { doxycycline } \\
444.43 \\
\text { (Fig. 4) }\end{array}$} & \multirow[t]{2}{*}{-} & \multirow[t]{2}{*}{-} & $\begin{array}{c}443.01 \\
{[\mathrm{M}-\mathrm{H}]^{-}}\end{array}$ & $\begin{array}{c}358.08 \\
{\left[\mathrm{M}-\mathrm{A}_{3}-\mathrm{H}\right]^{-}}\end{array}$ & $\begin{array}{c}217.00 \\
{\left[\mathrm{~A}_{1}-\mathrm{H}\right]^{-}}\end{array}$ & $\begin{array}{c}141.87 \\
{\left[\mathrm{~A}_{2}-\mathrm{H}\right]^{-}}\end{array}$ & $\begin{array}{c}273.05\left[\mathrm{M}-\mathrm{A}_{3}-\mathrm{A}_{4}-\mathrm{H}\right]^{-} \\
255.00\left[\mathrm{M}-\mathrm{A}_{2}-\mathrm{CO}\right. \\
\left.-\mathrm{H}_{2} \mathrm{O}-\mathrm{H}\right]^{-}\end{array}$ \\
\hline & & & $\begin{array}{l}445.16[\mathrm{M}+\mathrm{H}]^{+} \\
889.23[2 \mathrm{M}+\mathrm{H}]^{+} \\
\end{array}$ & \begin{tabular}{|c|}
428.14 \\
{$\left[\mathrm{M}-\mathrm{NH}_{3}+\mathrm{H}\right]^{+}$} \\
\end{tabular} & $\begin{array}{c}410.12\left[\mathrm{M}-\mathrm{NH}_{3}\right. \\
\left.-\mathrm{H}_{2} \mathrm{O}+\mathrm{H}\right]^{+}\end{array}$ & $\begin{array}{c}321.11\left[\mathrm{M}-\mathrm{A}_{2}\right. \\
\left.+\mathrm{H}_{2} \mathrm{O}+\mathrm{H}\right]^{+} \\
\end{array}$ & $\begin{array}{c}267.06 ; 201.03 ; 153.99 \\
{\left[\mathrm{~A}_{6}-\mathrm{NH}_{2} \mathrm{OH}+\mathrm{H}\right]^{+}} \\
\end{array}$ \\
\hline \multirow{2}{*}{$\begin{array}{c}\text { vancomycin } \\
1449 . \\
\text { (Fig. 5) }\end{array}$} & \multirow[t]{2}{*}{-} & \multirow[t]{2}{*}{-} & $-[\mathrm{M}-\mathrm{H}]-$ & $\begin{array}{c}1450.57 \\
{\left[\mathrm{M}-\mathrm{NH}_{2}\right.} \\
\left.+\mathrm{H}_{2} \mathrm{O}-\mathrm{H}\right]- \\
\end{array}$ & $\begin{array}{c}1404.95 \\
{\left[\mathrm{M}-\mathrm{CONH}_{2}\right]-}\end{array}$ & 1383.91 & $\begin{array}{c}1368.26 ; 1437.01 \\
1360.40\end{array}$ \\
\hline & & & $\begin{array}{r}1450.44 \\
{[\mathrm{M}+\mathrm{H}]+}\end{array}$ & 1489.22 & 1408.43 & 1379.03 & 1343.10 \\
\hline \multirow{2}{*}{$\begin{array}{c}\text { levofloxacin } \\
361.36\end{array}$} & & & $-[\mathrm{M}-\mathrm{H}]^{-}$ & 366.04 & 346.08 & 126.76 & $\begin{array}{c}697.27 ; 368.02 \\
140.96\end{array}$ \\
\hline & & & $-[\mathrm{M}+\mathrm{H}]^{+}$ & 314.13 & 245.15 & 231.07 & $\begin{array}{l}204.09 \\
332.13\end{array}$ \\
\hline
\end{tabular}

